Elsevier required licence: (C) <2018>. This manuscript version is made available under the CC-BY-NC-ND 4.0 license http://creativecommons.org/licenses/by-nc-nd/4.0/ 


\title{
Comparing the performance of brick and timber in residential buildings - The case of Australia
}

Thomas, D. \& Ding, G.

University of Technology Sydney

\begin{abstract}
There is currently a limited use of timber products in residential development in Australia due to the dominance of heavy materials such as concrete, steel and brick. This dominant use of heavy materials is a reversal of the traditional material choice that was based predominantly on timber products. Technological advances and efficiencies drove the change to heavy materials to use in residential construction. The emerging issue with this reliance on heavy materials is the impact of their use on the environment. The carbon impact and problem of finite resource depletion associated with concrete, steel and bricks need to be addressed due to the increasing pressure from national and international requirements and legislations. The construction industry needs to reduce its negative impact on the environment and the renewable nature of timber presents a material solution to the problem. Timber from sustainably managed forests and plantations can be utilised as lumber or manufactured into engineered products for residential development. This paper examines the benefits of timber used in building envelopes when compared with conventional high-density materials such as brick and concrete when construction is designed with equivalent thermal performance. Multiple case studies were used to demonstrate the reduced life cycle energy and costs, and the time of construction benefits of timber when used as an alternative to heavy materials. Results revealed that Life cycle energy and time of construction showed noticeable differences between timber construction and heavy materials and cost showing marginal differences.
\end{abstract}

Keywords: sustainable residential development, timber design, life cycle costing, life cycle energy, construction time 
Timber has been used in a single dwelling and multi-residential construction for many centuries throughout the world depending on the available resources, technologies and skilled artisans (Kolb 2008). Australian buildings have incorporated timber in a variety of forms drawing on the existing plentiful supply of local timbers (Cox, Freeland \& Stacey 1980). The last three to four decades have seen an increase in the use of reinforced concrete floors and brick external walls in single dwellings at the expense of timber structural floor and external wall cladding (University of Tasmania 2008; URS Corporation Australia 2010). Materials used in low rise residential have shifted from timber structural and decorative envelopes to mainly reinforced concrete and masonry structural systems. This has occurred due to the increased cost efficiencies and familiarity with concrete construction and durability/fire concerns with timber. Steel and reinforced concrete have been the exclusive structural material systems in medium and high-rise residential buildings until recent innovative timber construction methods emerged.

Current usage of materials for structural components of detached housing and multi-unit developments has been estimated by the construction industry and demonstrates the dominance of heavy materials such as steel and metal products, concrete, masonry products and glazing. Between $85-90 \%$ of new dwellings are built with external brick walls and concrete flooring (Kelly 2011). In multiunit residential dwellings the wall and floor systems were estimated to make up approximately $\$ 550$ million in revenue in 2011/12, mainly made up of steel, concrete and glass (Kelly 2011). The continued domination of heavy building materials that require large quantities of production energy is under question due to growing social and legislative requirements to reduce the carbon emissions produced by the construction industry.

The federal government in Australia has publicised commitments to reduce dramatically its year 2000 carbon emissions by 2050 and the New South Wales (NSW) plans to reduce its carbon impact by $60 \%$ over the next 40 years (NSW Department of Planning 2011; Australian Government 2012). However the majority of strategies focus on reducing buildings' operating energy use (Monahan \& Powell 2011) and less attention has been played in considering material choice at the design stage to reduce embodied energy. As these measures take effect there will be a greater need to reduce the production energy in the materials of construction (Mwashi, Williams \& Iwaro 2011). Timber and engineered timber products offer part of the solution to reducing life cycle energy due to timber being considered a renewable and low embodied energy material compared to conventional building materials (Perez 2008; John et al. 2011). Whilst government legislation and client expectation are driving an increase in the environmental sustainability of new buildings, material choice is still predominantly based on cost, time and quality factors which up until recently have led to the choice of conventional heavy materials in Australia (John et al. 2009; Holmes et al. 2011). 
The aims of this paper are to investigate whether timber used as a substitute to concrete and bricks in the envelope of residential construction provides performance benefits in regards to time, life cycle energy (LCE) and cost (LCC). The research uses multiple case studies to assess timber performance against the performance of heavy materials using the same criteria. The case studies will include the redesign of typical residential brick and concrete houses into a timber structure alternative with equivalent thermal performance to allow for a comparative study.

The research selects real life projects of conventional design using heavy materials for detached houses in NSW. Data analysis begins with examining the thermal performance rating of these detached houses and compares the LCE, LCC and time based on geographic location, gross floor area (GFA), and building orientation. These results will provide a platform for a redesigned timber envelope alternative that has equivalent thermal performance. The analysis will be carried out to ascertain the effect of a thermally equivalent timber design on aspects of LCE, LCC and time of construction when compared to the conventional heavy material design using a concrete and brick envelope.

\section{Timber use in residential development in Australia}

The increasing obligations on the construction industry to reduce its contribution to environmental damage come from both legislative mechanisms and public expectations. Additional incentives for material producers and builders to improve their environmental image comes from the marketing opportunities that provide access to 'green' money. The major material suppliers are all working to reduce the carbon emissions produced during the manufacture of their products such as using fly ash in concrete, replacing cement contend with waste produces in manufacturing masonry blocks and pavers (Flower \& Sanjayan 2007; Norgate, Jahanshahi \&Rankin 2007). The timber industry claims that timber can absorb and store more carbon during a tree's growth than is required during manufacture if it is burned for biofuel at the end of its lifecycle as an alternative to fossil fuels (Gustavsson \& Joelsson 2010).

Whilst studies in operating energy use in residential dwellings are plentiful there is limited research based on the building envelopes (construction system) and fewer still that examine different materials and their impact on LCE, LCC and construction time. While research studies focused on comparing different materials used for a typical house design (Carre 2011), there is limited research comparing timber against heavy materials in Australia based on thermal performance, LCE, LCC and construction time aspects. 
Timber is considered a renewable resource and timber structural envelopes have the potential to provide efficiencies in residential construction processes and reduce environmental impacts by decreases in the energy needed to construct, maintain and demolish residential developments compared to conventional methods and material uses. The benefits of using timber in residential construction have long been recognised to include low weight, high strength to weight ratio, easy to adjust on site, simple connections and high efficiency in erection, in addition to the architectural features and natural characteristics inherent in the product (Mahapatra \& Gustavsson 2009; Kolb 2008; Roos, Woxblam \& McKlusky 2010).

Timber can and has traditionally been used in most parts of a house's elements in Australia. The amount of timber used in Class 1 buildings fluctuates with the number of new houses and renovations commenced each year. The Australian Bureau of Statistics (ABS) monitors monthly housing approvals, which gives a good indication of the demand for materials that may be required in a given year (Low \& Mahendrajah 2010). The ABS reported an increase of $13 \%$ in private housing for the year ending 2014, indicating a continuous growth in the demand for housing and thus buildings materials (ABS 2014).

Structural elements such as wall and roof framing, decking structure and deck covering are dominated by the use of timber due to the speed of erection, cost and weight of the material. However, the use of brick as a veneer has dominated the market as the main wall material mainly due to greater thermal qualities, low maintenance, and resistance to decay and insect attack (University of Tasmania 2008). Up to $90 \%$ of new houses will have an external veneer of brickwork (IBISworld 2011). Concrete has dominated ground floor structure in the last 20 years with $80-85 \%$ usage in new houses (URS Forestry 2007; IBISworld 2011). These two material choices for floor and wall elements have become standard in most volume construction companies' typical products. This perpetuates the material selection because production efficiencies are based on consistent costs and a large consumer base. With only $5.6 \%$ of new houses built predominantly out of timber products, there is an opportunity for improving the market currently dominated by concrete and bricks for housing envelopes (IBISworld 2011).

\section{Perception of timber use in residential construction}

With the technologies available to use timber for residential structures instead of brick, steel and concrete, the reasons for the slow uptake of these structures require some attention. Misperception of timber use among stakeholders has been the major barrier for using timber in residential development. The primary stakeholders/drivers for materially specific dwellings include developers, design consultants and occupants. 
One of the main objectives of the developer when investing in construction projects is to receive a financial return on investment. In addition the end product they receive needs to fulfil the particular requirements set out in the planning or design phase of the project. Roos, Woxblom and McCluskey (2010) conduct semi-structured interviews and focus groups with Swedish construction professionals and confirmed that developers were primarily concerned with cost when considering construction material and method.

Architects have been viewed as the traditional specifiers of materials although other construction professionals can also influence the final choice (Yeomans 2008). The reasons for architects specifying wood products or avoiding their use depend upon their individual perception of and education in the material options (Bysheim \& Nyrud 2009; Bayne \& Taylor 2006). Some of these reasons are:

- Timber is highly regarded in aesthetic applications and is commonly chosen for features in multi-residential buildings (Nolan 2009)

- Timber is viewed as environmentally sustainable although this would be rated below technical reasons in their choice of materials (Wagner \& Hansen 2004)

- Structural limitations reduce the likelihood of timber selection in larger buildings (Roos, Woxblom \& McCluskey 2010)

- Fire and acoustic issues are viewed as difficult obstacles to overcome when timber construction is specified (Gold \& Rubik 2009)

Structural engineers are responsible for ensuring that buildings maintain their structural integrity. Included in the restraints they are faced with in material selection are the critical aspects of time, client preference, regulatory codes and the abilities of the other members of the design team (Knowles et al. 2010). Roos, Woxblom and McCluskey (2010) conducted an industry survey of the Swedish construction professionals and found that engineers are likely to design in materials they are familiar with and materials they have been educated in regarding load-bearing capacity such as concrete and steel. The engineers also expressed some doubt about the onsite fabrication process and the final structural performance of timber in larger buildings (Roos, Woxblom \& McCluskey 2010). Other disadvantages of the use of timber in multi-residential construction perceived by engineers include fire and acoustic resistance and the additional measures required to fulfil the associated legislative requirements (Nolan 2009).

Tenants and owners decision on the types of buildings constructed depending on their cultural setting and education in material properties. The use of timber is preferred by occupants for their soft features over other aspects, although purchase price/rental price is still a major consideration (Gold \& Rubik 2009). Soft features include environmental sustainability, attractiveness and the creation of 
a warm natural environment. According to Gold and Rubik (2009) the main reasons for occupants to prefer other materials to timber focus on its durability and maintenance. They also conducted a phone survey of 1,004 occupants in Germany and found that fire resistance and high maintenance are among timber's disadvantages as a construction product.

Ljunggren, Simmons and Hagberg (2014) compared occupants' perceptions of acoustic properties against the results of technical acoustic testing in Sweden of engineered timber, concrete, timber and steel frame multi-residential buildings against the results of technical acoustic testing. The result shows that occupants have most issues with the timber frame and light steel frame, and engineered timber performance is similar to concrete.

The negative perception of timber use in residential construction includes durability, structural capacity, fire resistance, acoustic and thermal performance, and insect resistance. Research has shown that fire, acoustic and durability issues can be overcome (Lennon et. al 2010; Ratnala \& Shrestha 2010; Alexander et al. 2014). However legislative challenges and high costs remain a concern. The supply side also lacked confidence in proposing timber (Roos, Woxblom \& McCluskey 2010). Lack of education about its performance and benefits is seen to be hindering the use of timber in addition to legislative barriers in building codes and standards (Mahapatra \& Gustavsson 2009).

\section{Research design}

From the literature search it reveals that misperception on the performance of timber among stakeholders in the construction industry has been the major obstacle for the uptake of timber in residential development in Australia. The research has been designed to conduct case studies using real projects in the industry. Multiple case studies have been used to compare performance between conventional heavy materials (i.e. concrete and brick) and timber on a typical design of detached dwelling in NSW.

\subsection{Case study projects}

Thirty-two projects were obtained from four residential developers and these were screened to ensure the inclusion of projects with sufficient information for the study. Pertinent information includes dimensioned architectural and structural drawings, specifications and site plans. Only roof design with concrete tiles are selected to keep the envelope structure consistent for the wall and floor redesign using timber. Metal roof projects were excluded as they require a lighter floor, wall and roof timber framing system.

Projects situated on steep sites are also excluded from the study as they will require more energy dependent heavy materials when compared to timber during the earthworks stage (Ding \& Forsythe 
2016). The study also showed that greater energy was required for earthworks in highly reactive soil or rock for heavy materials compared to timber houses. To avoid distorting results in favour of the timber structure in this study, sites with minimal slopes are used and subsoil conditions are to be $M$ class (moderately reactive clay). The age of the projects are to be constructed within the last five years so as to remove the influence of legislation and design changes.

After the screening process, ten projects were selected for the study. These are based both in Sydney suburbs and regional areas. The different seasonal climates may affect the heating and cooling requirements. Heating and cooling demand for the homes in particular regions changes with the seasons. These differing heating and cooling demands are calculated for each region or climatic zone by the thermal modelling software called AccuRate (see Section 4.1 for further details) to account for the thermal variations throughout a year. AccuRate enables the calculation of heating and cooling demands of homes based on material use, room size, insulation, position of the home and shading in different climatic zones in Australia.

Both one- and two-storey houses were included as well as different orientations to the sun. Table 1 summarises information of the projects selected for the study. The construction methods and materials used are the conventional design in Australia. The slabs are reinforced concrete waffle pods with edge beams and a single layer of brick with timber framing forming the external walls, timber roof trusses and covered with concrete or terra cotta tiles.

Table 1 - Summary of case study projects

\begin{tabular}{|c|c|c|c|}
\hline Project ID & No. of storeys & Gross floor area $\mathbf{( m}^{\mathbf{2}} \mathbf{~}$ & Location \\
\hline 1 & 2 & 290 & North \\
\hline 2 & 2 & 334 & East \\
\hline 3 & 1 & 171 & North \\
\hline 4 & 2 & 281 & South West \\
\hline 5 & 1 & 192 & North \\
\hline 6 & 2 & 246 & Eorth \\
\hline 7 & 2 & 260 & North \\
\hline 8 & 1 & 171 & West \\
\hline 9 & 2 & 240 & West \\
\hline 10 & 2 & 124 & \\
\hline
\end{tabular}

\subsection{Thermal performance analysis}

The thermal performance of the ten conventional projects (hereafter referred to brick for the paper) has been simulated using AccuRate. The analysis is to obtain thermal performance of each brick project so that equivalent thermal performance of timber redesign can be derived accordingly. AccuRate is a computer simulation program accepted as part of the Nationwide House Energy Rating Scheme approved by the Building Code of Australia (BCA). 
Thermal comfort of residential buildings has many influences including airflow, humidity, individual occupant inclinations and activity, and other combinations of factors (Moss et al. 2008). This leads to occupants heating and cooling to suit their particular preferences so it is challenging to predict accurately the energy required for the thermal conditioning of occupied premises. Thermal simulation software is often used in this respect to predict heating and cooling loads required of different designs, orientation, climate zone and insulation properties.

AccuRate requires inputs of material selections, envelope orientation, wall, floor and roof insulation, and shading devices in addition to aspects such as window size and thermal specifications. The output of the analysis is a star rating based on the particular climate area and an estimated annual heating and cooling energy requirement. The higher the star rating, the more efficient the building is for thermal conditioning and the lower the energy expenditure.

Table 2 presents the AccuRate star rating and simulation of heating and cooling load for the brick design of the case study projects. The brick design projects conform to BCA for thermal performance with the AccuRate star rating of $4+$ stars. The results in the table show generally that areas with hotter annual temperatures (average summer and winter temperature are $30^{\circ} \mathrm{C}$ and $17^{\circ} \mathrm{C}$ respectively) required greater cooling than heating (Projects 1, 3, 5, 6, 8 and 9 are all in the north of NSW) and projects in areas with mild temperatures (average summer and winter temperature are $28^{\circ} \mathrm{C}$ and $20^{\circ} \mathrm{C}$ respectively) have heating needs similar to cooling (Projects 2 and 7). The exceptions are the projects in the west or south west (average summer and winter temperature are $28^{\circ} \mathrm{C}$ and $5^{\circ} \mathrm{C}$ respectively) that require greater heating energy (Projects 4 and 10). Orientation also affected heating and cooling loads of two projects that are identical and both are found in the north (Projects 3 and 8). Project 8 orientated to the north has poorer thermal performance than Project 3 with the same design. The project requiring most annual energy made up almost entirely of heating was found in Project 10 that has a low average annual temperature and sub-zero winter temperatures.

Table 2 - Thermal star rating for the traditional brick veneer design for the case studies

\begin{tabular}{|c|c|c|c|c|c|c|}
\hline \multirow{2}{*}{$\begin{array}{l}\text { Project } \\
\text { ID }\end{array}$} & \multirow{2}{*}{$\begin{array}{c}\text { AccuRate Thermal } \\
\text { Rating (Stars) }\end{array}$} & Heating & Cooling & Total & \multirow{2}{*}{$\begin{array}{l}\text { GFA } \\
\left(\mathrm{m}^{2}\right)\end{array}$} & \multirow[t]{2}{*}{ Location } \\
\hline & & \multicolumn{3}{|c|}{$\mathrm{MJ} / \mathrm{m}^{2} /$ year } & & \\
\hline 1 & 5.9 & 40.2 & 49.4 & 89.6 & 290 & North \\
\hline 2 & 5.8 & 24.8 & 28.4 & 53.2 & 334 & East \\
\hline 3 & 5.4 & 40.8 & 58.9 & 99.7 & 171 & North \\
\hline 4 & 4.9 & 75.1 & 30.2 & 105.3 & 281 & South West \\
\hline 5 & 5.6 & 44.0 & 52.7 & 96.7 & 192 & North \\
\hline 6 & 5.2 & 46.1 & 63.5 & 109.6 & 246 & North \\
\hline 7 & 6.1 & 24.5 & 25.0 & 49.5 & 260 & East \\
\hline 8 & 4.7 & 58.0 & 66.3 & 121.3 & 171 & North \\
\hline 9 & 6.2 & 17.6 & 31.0 & 48.6 & 240 & North \\
\hline 10 & 4.9 & 288.5 & 7.6 & 296.1 & 124 & West \\
\hline
\end{tabular}




\subsection{Timber redesign of building envelope}

The ten brick projects were redesigned using timber and engineered timber so that a comparative study can be undertaken. A number of factors were considered in redesigning the brick projects to incorporate a timber optimised alternative. These factors include similar thermal ratings, compliance to BCA and Australian Standards, and maintain the same functional areas.

The main purpose of redesigning is to achieve a thermal performance equivalent to the brick design so that comparative study for LCE, LCC and construction time can be undertaken. According to the thermal star rating of the ten brick designs (Table 2 ) a variety of timber envelope options are investigated to obtain the design that produce an equivalent thermal performance. The main differences noted between the brick and the timber design occurred in the groundworks, substructure and wall elements.

Based on the AccuRate thermal star rating results of the brick designs, these projects have been redesigned to match the thermal performance through changes in the structural components of the floor and sub-floor, external wall and lining, and roof. The timber design has been in accordance with the Timber Framing Code of Australia and verified by a structural engineer in the industry. Sizing of the wall/floor structure and cladding are selected to incorporate standard timber sizes and structural performance. The floor structure included the use of timbers that are both insect and moisture resistant and can take the load of the wall and roof structure. This is required to allow for the additional weight of timbers in the wall due to increased sizes. The increased width of wall frames has flow on effects for door jambs and window reveals that may increase the cost and material volume. Using timber cladding for covering of the exterior of wall envelope may require ongoing painting and other maintenance requirements.

Table 3 summarises materials used for both designs of the ten projects. The materials have been categorised into building elements to facilitate comparison. The material systems for both design options include using brick and concrete for conventional design and standard material sizing for the redesigned timber alternative. Material sizing and choice of envelope also considered the most efficient way to achieve equivalent thermal rating in both designs. The process of calculating the thermal performance of the two different designs along with the method of calculating LCE and LCC are discussed in the next section. 
Table 3 - Building envelope materials for conventional and timber design

\begin{tabular}{|c|c|c|}
\hline $\begin{array}{c}\text { Building } \\
\text { Component }\end{array}$ & $\begin{array}{c}\text { Conventional design } \\
\text { (Brick veneer envelope) }\end{array}$ & $\begin{array}{c}\text { Timber design } \\
\text { (Timber clad envelope) }\end{array}$ \\
\hline Substructure & $\begin{array}{l}\text { Sand blinding } \\
\text { Concrete piers (in area of fill) } \\
\text { 200um Waterproof membrane }\end{array}$ & $\begin{array}{l}\text { Concrete piers } \\
\text { Galvanised steel piers-braced } \\
19 \mathrm{~mm} \text { timber cladding wall enclosure }\end{array}$ \\
\hline Structural floor & $\begin{array}{l}\text { Ground floor: } \\
\text { EPS foam, reinforced concrete floor \& } \\
\text { ribs } \\
\text { First floor: } \\
\text { Timber I-beams \& chipboard }\end{array}$ & $\begin{array}{l}\text { Ground floor: } \\
\text { 140mm Treated pine bearers, R3.1 insulation, } \\
\text { 90-120mm treated pine joists \& } 12 \mathrm{~mm} \text { Ply } \\
\text { under floor covering } \\
\text { First floor: } \\
\text { Timber I-beams \& chipboard }\end{array}$ \\
\hline Floor finishes & $\begin{array}{l}\text { Ground floor: } \\
\text { Carpet with underlay or ceramic tiles } \\
\text { First floor: } \\
\text { Carpet with underlay }\end{array}$ & $\begin{array}{l}\text { Ground floor: } \\
19 \mathrm{~mm} \text { Hardwood flooring or Ceramic tiles on } \\
15 \mathrm{~mm} \text { fibrous cement sheeting } \\
\text { First floor: } \\
\text { Carpet with underlay }\end{array}$ \\
\hline External wall & $\begin{array}{l}\text { Structure: } \\
\text { 90mm Pine timber frame, vapour } \\
\text { barrier \&50mm air cavity } \\
\text { Lining to the inside: } \\
10 \mathrm{~mm} \text { Plasterboard } \\
\text { External cladding: } \\
\text { Extruded clay brick }\end{array}$ & $\begin{array}{l}\text { Structure: } \\
\text { 145mm Treated pine framing, R3.1 insulation } \\
\text { batts, vapour barrier \& } 38 \mathrm{~mm} \text { air } \\
\text { cavity/vertical battens } \\
\text { Lining to the inside: } \\
\text { 10mm Plasterboard } \\
\text { External cladding: } \\
\text { Painted timber cladding \& timber architraves }\end{array}$ \\
\hline Roofing & $\begin{array}{l}\text { Structure: } \\
\text { Pine timber frame/truss, R3.5 } \\
\text { insulation to living areas } \\
\text { Covering: } \\
\text { Roof sarking \& concrete tiles }\end{array}$ & $\begin{array}{l}\text { Structure: } \\
\text { MGP } 10 \text { Pine Timber frame/truss, R3.5 } \\
\text { insulation to living areas } \\
\text { Covering: } \\
\text { Roof sarking \& concrete tiles }\end{array}$ \\
\hline
\end{tabular}

5. Analysis

\subsection{Thermal performance}

Table 4 presents the AccuRate thermal star rating for both the brick and the optimised timber designs. The star ratings of the timber design have achieved the closest to the AccuRate ratings of the brick design. Projects 2, 7 and 9 in the table were the most efficient in thermal conditioning energy requirements. These were all two-storey houses and the shading over windows and walls may have contributed significantly to the relatively low heating/cooling performance. Each house has a number of wing walls, awnings and first floor balconies that have provided shading for different parts of the building during the day. 
Table 4 - Comparison of thermal conditioning between conventional and timber designs for the case study projects

\begin{tabular}{|c|c|c|c|c|c|c|}
\hline \multirow[t]{2}{*}{ Project ID } & \multicolumn{2}{|c|}{$\begin{array}{c}\text { Thermal Star Rating } \\
\text { (Stars) }\end{array}$} & \multicolumn{2}{|c|}{$\begin{array}{l}\text { Heating \& cooling } \\
\text { (MJ/m²/year) }\end{array}$} & \multirow{2}{*}{$\begin{array}{l}\text { GFA } \\
\left(\mathrm{m}^{2}\right)\end{array}$} & \multirow[t]{2}{*}{ Location } \\
\hline & Brick & Timber & Brick & Timber & & \\
\hline 1 & 5.9 & 5.6 & 89.6 & 95.5 & 290 & North \\
\hline 2 & 5.8 & 6.0 & 53.2 & 44.2 & 334 & East \\
\hline 3 & 5.4 & 5.0 & 99.7 & 115.1 & 171 & North \\
\hline 4 & 4.9 & 5.8 & 105.3 & 86.5 & 281 & South West \\
\hline 5 & 5.6 & 5.5 & 96.7 & 98.1 & 192 & North \\
\hline 6 & 5.2 & 5.4 & 109.6 & 102.1 & 246 & North \\
\hline 7 & 6.1 & 6.1 & 49.5 & 50.3 & 260 & East \\
\hline 8 & 4.7 & 4.2 & 121.3 & 137.7 & 171 & North \\
\hline 9 & 6.2 & 6.1 & 48.6 & 49.4 & 240 & West \\
\hline 10 & 4.9 & 5.4 & 296.1 & 252.9 & 124 & West \\
\hline
\end{tabular}

The thermal comparison shows that only Project 7 has achieved the same thermal star rating and the remaining projects are up to 0.5 star above or below the brick projects. In order to examine the effect of these subtle differences a 50-year thermal load analysis has been carried out to examine the potential impact on LCE for the timber designs. This has been calculated by first determining the value of 0.1 star rating in energy consumption $\left(\mathrm{MJ} / \mathrm{m}^{2}\right)$. This is then multiplied by the number of 0.1 stars difference between the brick and timber designs. This is then multiplied by the GFA of each project. The results indicated that the adjusted thermal analysis did not impact significantly on the LCE of the timber design.

Figure 1 - Thermal performance of brick versus timber design ( $\mathrm{MJ} / \mathrm{m}^{2} /$ year)

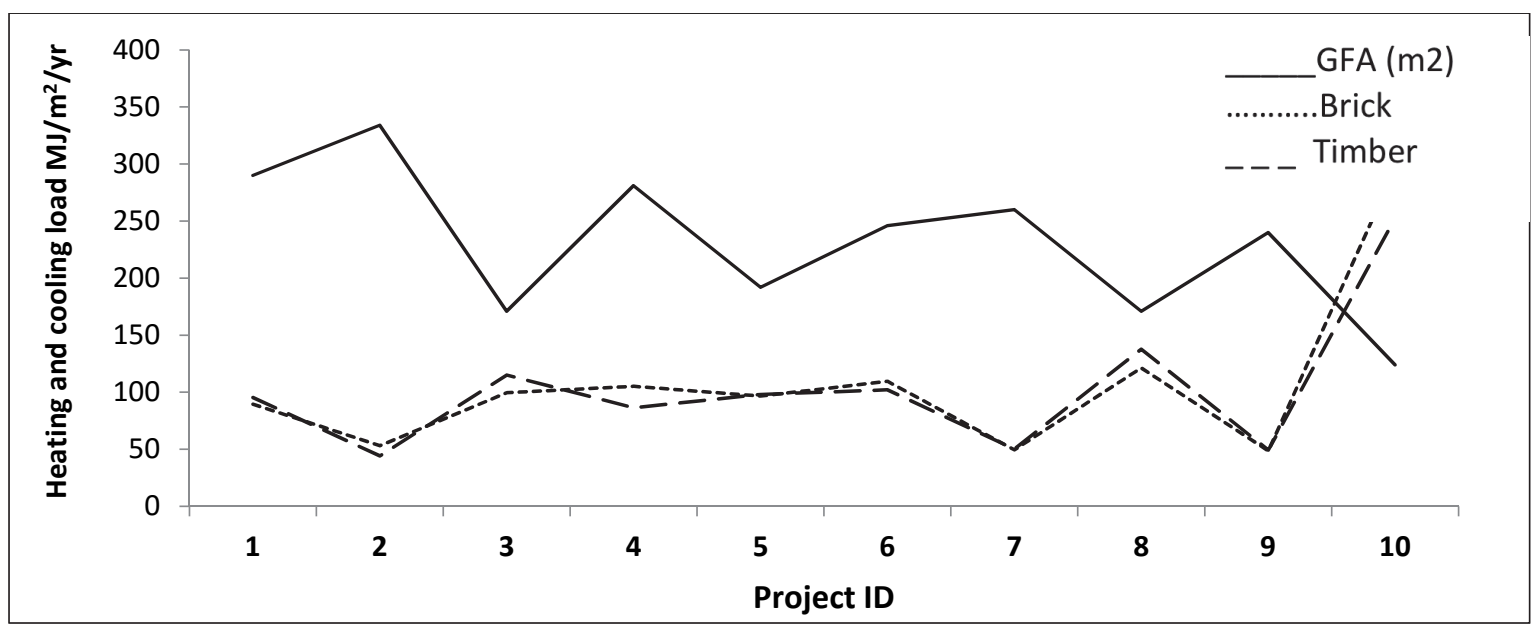

Figure 1 shows the energy use for heating and cooling per square metre for each project per annum. The figure shows that the thermal performance for both designs is very similar for almost every project. It also shows a reducing thermal load as the projects begin to increase in GFA. This may be caused by smaller roof spaces for two storey houses and greater thermal efficiency in the downstairs living areas due to thermal insulation from the first floor structure. 
From the table and the figure, there is only a slight difference between the brick and timber thermal star rating performance. This demonstrates that it is possible to achieve similar thermal performance for timber design compared to conventional heavy materials in providing similar thermal comfort. Therefore the perception provided in the literature that timber is inferior in thermal performance to heavy materials is less accurate. The capacity of timber being able to achieve equivalent thermal performance also means that LCE, LCC and construction time can be compared to buildings with similar thermal star ratings.

\subsection{Life cycle energy analysis (LCE)}

LCE has been calculated based on a system boundary of cradle-to-grave that includes the stages of construction, maintenance and end of life on a 50-year lifecycle. Energy consumed at the construction stage includes initial embodied energy in material manufacturing, material waste during construction, energy used in major plant and equipment for construction activities on site. The energy required for transportation of operatives to and from site has been excluded as it will be similar to both designs.

Initial embodied energy for all the processes and materials relating to all the projects have been quantified and developed into an inventory dataset for the study. A list of environmental profiles associated with each unit process was determined using the LCI database from the ICE v2.0, GaBi ${ }^{1}$ and eTool ${ }^{2}$. A summary of the key materials used for the study is presented in Table 5. The energy consumption at this stage will also include fuel consumption for plants and equipment used for construction activities onsite.

Table 5 - Summary of key materials and energy intensity for the case study projects

\begin{tabular}{|l|c|}
\hline \multicolumn{1}{|c|}{ Key materials } & Energy intensity \\
\hline Cement & $4.2 \mathrm{MJ} / \mathrm{kg}$ \\
\hline Sand & $0.6 \mathrm{MJ} / \mathrm{kg}$ \\
\hline Aggregate & $0.03 \mathrm{MJ} / \mathrm{kg}$ \\
\hline Steel reinforcing bars & $16 \mathrm{MJ} / \mathrm{kg}$ \\
\hline Softwood & $7.5 \mathrm{MJ} / \mathrm{kg}$ \\
\hline Insulation & $28 \mathrm{MJ} / \mathrm{kg}$ \\
\hline Brick & $3 \mathrm{MJ} / \mathrm{kg}$ \\
\hline Brick mortar & $1.1 \mathrm{MJ} / \mathrm{t}$ \\
\hline Plasterboard & $6.8 \mathrm{MJ} / \mathrm{kg}$ \\
\hline Paint & $31.5 \mathrm{MJ} / \mathrm{kg}$ \\
\hline Fibrous cement sheeting & $10.5 \mathrm{MJ} / \mathrm{m}^{3}$ \\
\hline Timber l-Joist & $22.4 \mathrm{MJ} / \mathrm{m}^{3}$ \\
\hline
\end{tabular}

Sources: ICE v2.0, GaBi LCl, eTool

\footnotetext{
${ }^{1} \mathrm{GaBi}$ - www.gabi-software.com

${ }^{2}$ eTool - www.etoolglobal.com
} 
At the operating stage buildings are maintained and refurbished throughout its lifecycle in order to maintain the functional capacity. Therefore over a building's service life one or multiple replacements may require. The energy consumption during this stage is measured as recurrent embodied energy (REE) when they relate to the use of materials and components to maintain and refurbish the building over it lifetime. Table 8 presents the lifespan of key materials/components for maintenance and refurbishment in residential buildings. Therefore the service life and durability of materials/components are among the most important factors affecting the REE calculation. The shorter the service life, the greater the quantity of ongoing maintenance and refurbishment and the greater will be the REE associated with manufacturing and installing replacement materials throughout a building's lifecycle. The REE is calculated by the quantity of materials/components used for maintenance or refurbishment and multiplied by the replacement times and associated energy intensity. However operating energy has not been included in the study as it would be similar to both designs due to the equivalent thermal rating.

Finally at the end-of-life stage energy consumption includes demolition activities and disposal of waste to landfill or recycling centres. At the end of 50-year period it was assumed that each house is to be demolished and sent to landfill. The energy consumption at this stage will include fuel consumption for plants and equipment used in the demolition of these houses at the end of life stage and fuel consumption for the disposal of demolition waste to landfill.

Table 6 compares LCE between brick and the redesigned timber designs. The table shows that timber design has a lower LCE than brick design on all projects. Timber design on average has consumed approximately $10 \%$ less LCE than the brick design on a 50 -year lifecycle. The breakdown of LCE by stages for both brick and timber designs has been presented in Table 7.

Table 6 - Comparison of lifecycle energy between brick and timber design

\begin{tabular}{|c|c|c|c|c|c|c|c|}
\hline \multirow[t]{2}{*}{$\begin{array}{l}\text { Project } \\
\text { ID }\end{array}$} & \multirow[t]{2}{*}{$\begin{array}{l}\text { GFA } \\
\left(m^{2}\right)\end{array}$} & \multicolumn{2}{|c|}{$\begin{array}{l}\text { AccuRate Thermal Rating } \\
\text { (Stars) }\end{array}$} & \multicolumn{2}{|c|}{$\begin{array}{c}\text { LCE (50 years) } \\
\text { (MJ) }\end{array}$} & \multicolumn{2}{|c|}{$\begin{array}{c}\text { LCE (50 years) } \\
\left(\mathrm{MJ} / \mathrm{m}^{2}\right)\end{array}$} \\
\hline & & Brick & Timber & Brick & Timber & Brick & Timber \\
\hline 1 & 290 & 5.9 & 5.6 & $2,230,507$ & $2,009,116$ & 7,691 & 6,928 \\
\hline 2 & 334 & 5.8 & 6.0 & $3,051,217$ & $2,827,444$ & 9,135 & 8,465 \\
\hline 3 & 171 & 5.4 & 5.0 & $1,900,948$ & $1,708,336$ & 11,117 & 9,990 \\
\hline 4 & 281 & 4.9 & 6.2 & $2,471,915$ & $2,234,080$ & 8,797 & 7,950 \\
\hline 5 & 192 & 5.6 & 5.5 & $1,947,019$ & $1,760,811$ & 10,141 & 9,171 \\
\hline 6 & 246 & 5.2 & 5.4 & $2,475,470$ & $2,221,483$ & 10,063 & 9,030 \\
\hline 7 & 260 & 6.1 & 6.1 & $2,476,941$ & $2,274,446$ & 9,527 & 8,748 \\
\hline 8 & 171 & 4.7 & 4.2 & $1,851,943$ & $1,696,303$ & 10,830 & 9,920 \\
\hline 9 & 240 & 6.2 & 6.1 & $2,122,896$ & $1,943,651$ & 8,845 & 8,099 \\
\hline 10 & 124 & 4.9 & 5.4 & $1,144,086$ & $1,037,806$ & 9,226 & 8,369 \\
\hline Mean & 231 & 5.5 & 5.6 & $2,167,294$ & $1,971,348$ & 9,537 & 8,667 \\
\hline
\end{tabular}


Table 6 shows that timber design is consistently lower in LCE than brick design on all projects. The total LCE per $\mathrm{m}^{2}$ GFA averaged $9,537 \mathrm{MJ} / \mathrm{m}^{2}$ for brick and $8,667 \mathrm{MJ} / \mathrm{m}^{2}$ for timber, which is approximately $10 \%$ more on a lifecycle perspective.

The material and construction phase is the phase that consumes most of the LCE, $59 \%$ and $54 \%$ respectively for brick and timber designs (Table 7). The average energy per $\mathrm{m}^{2}$ is $5,588 \mathrm{MJ} / \mathrm{m}^{2}$ for brick and $4,717 \mathrm{MJ} / \mathrm{m}^{2}$ for timber, which is approximately $18 \%$ different. At the maintenance stage the brick and timber designs consume approximately 40 and 45\% respectively. The average energy consumption at this stage for timber is only about $2 \%$ more than brick. The end-of-life phase consumes less than $2 \%$ of the LCE. The end-of-life energy is much higher for brick $\left(163 \mathrm{MJ} / \mathrm{m}^{2}\right)$ than timber $\left(103 \mathrm{MJ} / \mathrm{m}^{2}\right)$, which is approximately $58 \%$ more. The LCE analysis demonstrates energy embodied in heavy materials presents a significant opportunity for reduction LCE through the use of alternate materials.

Table 7 - Summary of lifecycle energy by stages per $\mathrm{m}^{2}$ GFA

\begin{tabular}{|c|c|c|c|c|c|c|c|c|}
\hline \multirow{3}{*}{$\begin{array}{c}\text { Project } \\
\text { ID }\end{array}$} & \multicolumn{2}{|c|}{$\begin{array}{l}\text { Material \& } \\
\text { Construction }\end{array}$} & \multicolumn{2}{|c|}{$\begin{array}{c}\text { Maintenance } \\
\text { (50 years lifespan) }\end{array}$} & \multicolumn{2}{|c|}{$\begin{array}{c}\text { End-of-life } \\
\text { (Demolition \& disposal) }\end{array}$} & \multicolumn{2}{|c|}{ Total } \\
\hline & Brick & Timber & Brick & Timber & Brick & Timber & Brick & Timber \\
\hline & \multicolumn{8}{|c|}{ Life Cycle Energy (MJ/m² GFA) } \\
\hline 1 & 4,533 & 3,693 & 3,047 & 3,164 & 111 & 70 & 7,691 & 6,928 \\
\hline 2 & 5,213 & 4,532 & 3,810 & 3,857 & 112 & 76 & 9,135 & 8,465 \\
\hline 3 & 6,743 & 5,627 & 4,114 & 4,212 & 260 & 151 & 11,117 & 9,990 \\
\hline 4 & 5,075 & 4,278 & 3,609 & 3,601 & 113 & 71 & 8,797 & 7,950 \\
\hline 5 & 6,067 & 5,062 & 3,831 & 3,954 & 242 & 155 & 10,140 & 9,171 \\
\hline 6 & 5,804 & 4,794 & 4,140 & 4,163 & 119 & 74 & 10,063 & 9,030 \\
\hline 7 & 5,457 & 4,629 & 3,954 & 4,044 & 117 & 75 & 9,527 & 8,748 \\
\hline 8 & 6,375 & 5,517 & 4,180 & 4,229 & 275 & 174 & 10,830 & 9,920 \\
\hline 9 & 5,033 & 4,171 & 3,716 & 3,866 & 97 & 61 & 8,845 & 8,099 \\
\hline 10 & 5,584 & 4,868 & 3,458 & 3,379 & 184 & 122 & 9,226 & 8,369 \\
\hline Mean & 5,588 & 4,717 & 3,786 & 3,847 & 163 & 103 & 9,537 & 8,667 \\
\hline$\%$ & 58.6 & 54.4 & 39.7 & 44.5 & 1.7 & 1.2 & 100 & 100 \\
\hline
\end{tabular}

Figure 2 shows the comparison between timber and brick LCE. The energy embodied in windows/doors make up the largest proportion of LCE as they have a replacement life of 25 years and are replaced twice in the lifecycle. The figure shows that groundworks for brick design is higher in most projects than timber design. The most influential elements in LCE are substructure and external walls most likely due to the impact of concrete and bricks in the heavy material projects and despite the replacement of timber cladding in the timber projects. Wall finishes are slightly higher for timber due to external painting that is not required for brick veneer homes. Floor finishes are similar with the exception of where timber flooring is used instead of tiling. 
Figure 2 - Distribution of LCE across building elements (excluding end of life energy)

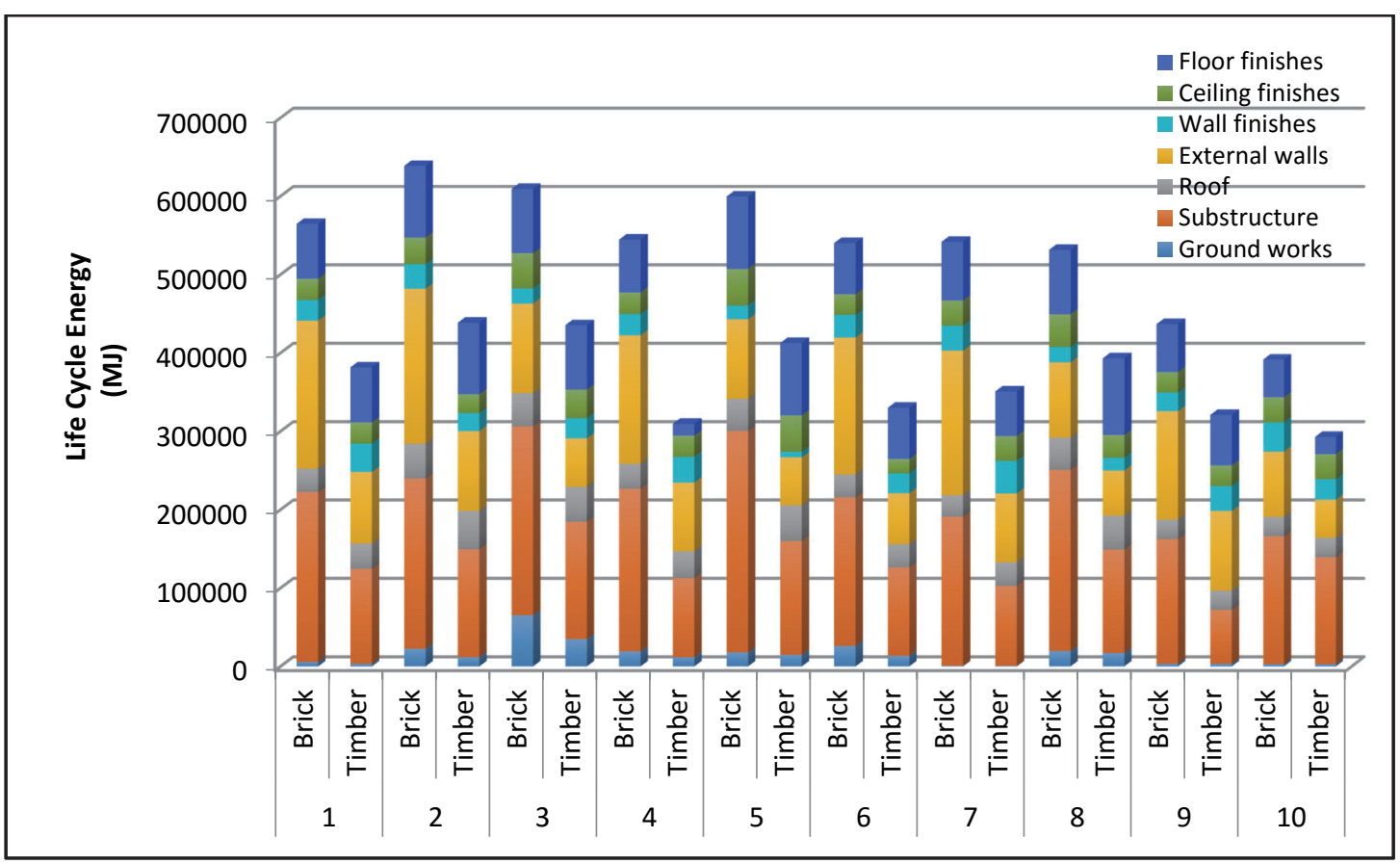

In summary the analysis reveals that timber requires approximately $18 \%$ less LCE than brick for the 50 years of service when based on equivalent thermal performance. The substructure and external wall elements have the greatest influence on the difference in embodied energy between brick and timber projects which is in favour of timber design. It is noted that percentage comparisons exclude the use phase in calculations.

\subsection{Life cycle costing (LCC)}

LCC have been calculated for both the brick and timber designs on a lifecycle of 50 years that includes initial construction costs, maintenance and end of life disposal. Owner and operating costs are excluded in the calculation as these will be the same for both designs. Costs for maintenance and demolition are based on industry rates and are calculated for both designs at a discount rate of $5 \%$. This is necessary as maintenance occurs intermittently over 50 years and demolition is assumed to take place in 50 years. Table 8 presents the items that are required for maintenance and the associated life span. 
Table 8 - Replacement times for maintenance and demolition items

\begin{tabular}{|l|l|c|c|c|}
\hline \multicolumn{1}{|c|}{ Maintenance Items } & \multicolumn{1}{|c|}{ Inclusions } & \multicolumn{1}{c|}{$\begin{array}{c}\text { Life span } \\
\text { (Years) }\end{array}$} & Brick & Timber \\
\hline Internal painting & Paint and labour & 10 & $\checkmark$ & $\checkmark$ \\
\hline External painting & Paint and labour & 7 & X & $\checkmark$ \\
\hline Bathroom/laundry tiles & $\begin{array}{l}\text { Demolition/disposal, } \\
\text { waterproof, FC wall } \\
\text { sheets, tiling, fixtures }\end{array}$ & 25 & $\checkmark$ & $\checkmark$ \\
\hline Garage door & Disposal/Supply and install & 25 & $\checkmark$ & $\checkmark$ \\
\hline Windows (internal architraves & $\begin{array}{l}\text { Disposal/Supply and } \\
\text { install/ paint windows \& } \\
\text { architraves }\end{array}$ & 25 & $\checkmark$ & $\checkmark$ \\
\hline Ceramic tiles & $\begin{array}{l}\text { Disposal/Underlay/ carpet, } \\
\text { installation }\end{array}$ & 25 & $\checkmark$ & $\checkmark$ \\
\hline External doors & $\begin{array}{l}\text { Disposal/Supply and } \\
\text { install/ hardware/ paint }\end{array}$ & 25 & $\checkmark$ & $\checkmark$ \\
\hline External door frames \& architraves & Supply, install and paint & 25 & $\checkmark$ & $\checkmark$ \\
\hline Timber cladding & $\begin{array}{l}\text { Disposal/Supply and install } \\
\text { and paint }\end{array}$ & 25 & $X$ & $\checkmark$ \\
\hline Demolition & Entire house + footings & 50 & $\checkmark$ & $\checkmark$ \\
\hline Disposal & Entire house + footings & 50 & $\checkmark$ & $\checkmark$ \\
\hline
\end{tabular}

Source: AIQS 2002; RICS 2006

Table 8 shows the life span for material replacement and maintenance for the brick and timber designs. Exclusions from the LCC study are the interior fitout and services, and operating costs as they are common to both designs. Other costs such as land purchase, design consultants, legal services and approvals have also been excluded from the calculations for the same reason. The LCC study includes excavation, retaining walls, house construction, maintenance costs and end-of-life disposal. Due to the slight difference in the thermal star rating between the brick and timber designs an operating cost comparison has been conducted to analyse the cost implication of slightly different in the thermal load requirements between the two designs.

The method used to calculate the impact of 0.1 star is first to establish the average break up of domestic energy use in NSW. The information is obtained from an energy break up report for families and an IPART report of the average 5-person household energy usage (IPART 2013; NSW Government 2011). The heating and energy load information is used to calculate the total operational costs for both the brick and timber designs. Over a 50-year lifecycle there is only a cost difference of $0.00075 \%$ per 0.1 AccuRate star rating. Due to the insignificant cost impact on the overall cost comparison, no adjustments have been made to the final LCC comparison between for the two designs. Table 8 summarises the LCC of the ten project for the both designs. 
Table 9 - Comparison of life cycle costs between brick and timber designs

\begin{tabular}{|c|c|c|c|c|c|c|c|}
\hline \multirow{2}{*}{ Project ID } & \multirow{2}{*}{$\begin{array}{c}\text { GFA } \\
\left(\mathbf{m}^{2}\right)\end{array}$} & \multicolumn{2}{|c|}{$\begin{array}{c}\text { Thermal Star } \\
\text { Rating (Stars) }\end{array}$} & \multicolumn{2}{|c|}{$\begin{array}{c}\text { LCC (50 years) } \\
\mathbf{( \$ )}\end{array}$} & \multicolumn{2}{c|}{$\begin{array}{c}\text { LCC } \mathbf{( 5 0} \text { years) } \\
\left(\mathbf{\$} / \mathbf{m}^{\mathbf{2}} \mathbf{)}\right.\end{array}$} \\
\cline { 3 - 8 } & & Brick & Timber & Brick & Timber & Brick & Timber \\
\hline 1 & 290 & 5.9 & 5.6 & 179,366 & 179,464 & 618 & 619 \\
\hline 2 & 334 & 5.8 & 6.0 & 229,612 & 225,657 & 688 & 676 \\
\hline 3 & 171 & 5.4 & 5.0 & 215,684 & 190,336 & 1,261 & 1,113 \\
\hline 4 & 281 & 4.9 & 6.2 & 186,158 & 170,822 & 662 & 608 \\
\hline 5 & 192 & 5.6 & 5.5 & 193,320 & 196,297 & 1,007 & 1,022 \\
\hline 6 & 246 & 5.2 & 5.4 & 178,372 & 164,434 & 725 & 668 \\
\hline 7 & 260 & 6.1 & 6.1 & 184,072 & 178,514 & 708 & 687 \\
\hline 8 & 171 & 4.7 & 4.2 & 176,638 & 187,807 & 1,033 & 1,098 \\
\hline 9 & 240 & 6.2 & 6.1 & 148,430 & 160,556 & 619 & 669 \\
\hline 10 & 124 & 4.9 & 5.4 & 123,881 & 118,873 & 999 & 959 \\
\hline Mean & $\mathbf{2 3 1}$ & $\mathbf{5 . 5}$ & $\mathbf{5 . 6}$ & $\mathbf{1 8 1 , 5 5 3}$ & $\mathbf{1 7 7 , 2 7 6}$ & $\mathbf{8 3 2}$ & $\mathbf{8 1 2}$ \\
\hline
\end{tabular}

From the table Projects 5, 8 and 9 are more expensive in the timber design and the remaining projects are more expensive for the brick design. The single-storey projects (Projects 3, 5 and 8) appear to be more expensive than the other and this may be due to larger roof area to GFA ratio compared to twostorey projects that have a smaller roof to GFA ratio. On average the timber design is cheaper than brick design by approximately $2 \%$ The LCC phase has also been presented in Table 9.

Table 10 - Summary of LCC by stages per $m^{2}$ GFA

\begin{tabular}{|c|c|c|c|c|c|c|c|c|}
\hline \multirow{3}{*}{$\begin{array}{l}\text { Project } \\
\text { ID }\end{array}$} & \multicolumn{8}{|c|}{ LCC (\$/m² GFA) } \\
\hline & \multicolumn{2}{|c|}{$\begin{array}{c}\text { Material \& } \\
\text { Construction }\end{array}$} & \multicolumn{2}{|c|}{$\begin{array}{c}\text { Maintenance } \\
\text { (50 years life span) }\end{array}$} & \multicolumn{2}{|c|}{ End of life } & \multicolumn{2}{|c|}{ Total LCC } \\
\hline & Brick & Timber & Brick & Timber & Brick & Timber & Brick & Timber \\
\hline 1 & 542 & 514 & 70 & 100 & 6 & 5 & 618 & 619 \\
\hline 2 & 602 & 566 & 80 & 104 & 6 & 5 & 688 & 676 \\
\hline 3 & 1129 & 960 & 121 & 145 & 11 & 9 & 1261 & 1113 \\
\hline 4 & 582 & 515 & 75 & 89 & 5 & 4 & 662 & 608 \\
\hline 5 & 884 & 872 & 112 & 142 & 11 & 9 & 1007 & 1022 \\
\hline 6 & 631 & 550 & 88 & 114 & 6 & 5 & 725 & 668 \\
\hline 7 & 612 & 565 & 90 & 117 & 6 & 5 & 708 & 687 \\
\hline 8 & 901 & 938 & 120 & 151 & 12 & 8 & 1033 & 1098 \\
\hline 9 & 535 & 553 & 78 & 112 & 6 & 4 & 619 & 669 \\
\hline 10 & 851 & 804 & 137 & 147 & 11 & 8 & 999 & 959 \\
\hline Mean & 727 & 684 & 97 & 122 & 8 & 6 & 832 & 812 \\
\hline$\%$ & 87.2 & 84.0 & 11.8 & 15.3 & 1.0 & 0.7 & 100 & 100 \\
\hline
\end{tabular}

As shown in Table 10 the material and construction costs make up the majority of the LCC with $87 \%$ and $84 \%$, whereas the maintenance costs are significantly lower at $12 \%$ and $15 \%$ respectively for brick and timber designs. At the material and construction phase the table shows that all but two projects ( 8 and 9) have greater for timber design, approximately $4 \%$ and $3 \%$ higher than brick design. On average the timber design is approximately $6 \%$ cheaper than brick design. Maintenance costs are greater for timber design in all projects which on average is approximately $26 \%$ more expensive than brick design. The reason for higher maintenance costs can be attributed to the painting and replacement of timber cladding throughout the 50-year lifecycle. At the end-of-life costs with brick 
showing an average of $1 \%$ whereas timber at $0.7 \%$, which is approximately $30 \%$ more expensive than timber design. The additional costs are associated with additional use of plant to demolish brick and concrete and by weight of waste for disposal at landfills or recycling centres. Plant hire for demolition is charged by the hour and construction waste by the weight.

The LCC was also analysed by major building elements for both designs. The breakdown of costs into elements is presented in Figure 3 for brick and timber designs to better understand how the majority of costs are distributed. The figure shows the distribution of costs across the building elements. The wide range in the groundworks is related to the requirement and size of retaining walls and extent of excavation activity. Substructure costs vary according to the footprint and sloping of the land. Projects with smaller footprints have less cost on roofing, reinforcement, formwork and concrete than the projects with larger footprint.

Figure 3 - Distribution of costs across building elements for brick and timber buildings

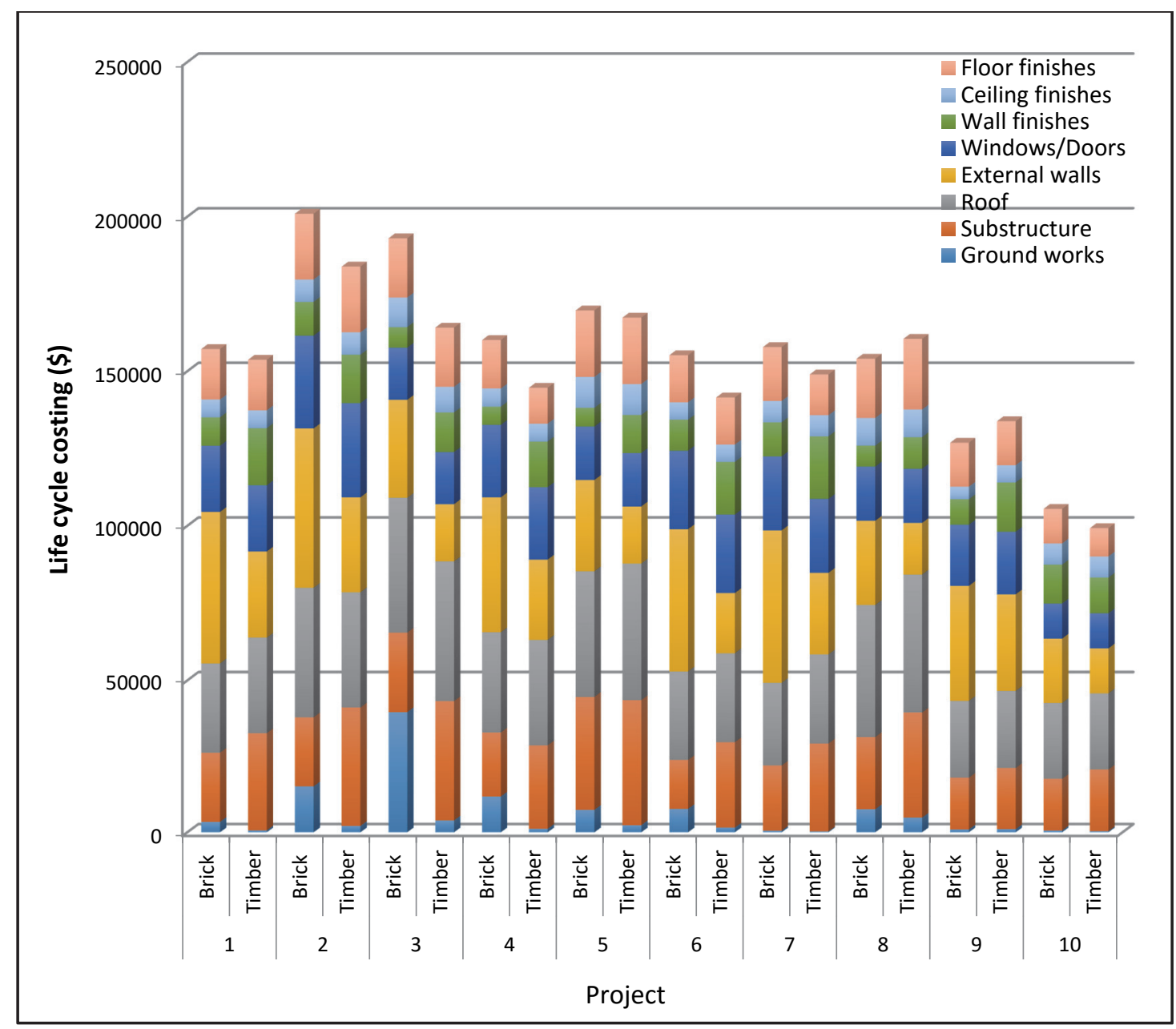

As expected, the two-storey houses with larger external walls are greater in cost than single-storey projects and window and door cost are proportionate to the surface area of glazing/doors. The element cost breakdown in Figure 3 also shows that groundworks are greater in the brick design, 
which is most likely related to cut and fill and retaining structure activities. Project 3 stands out due to a large amount of cut and fill and associated soil retention structures. Timber designs require less cut and fill and soil retention, however, there is significant material and labour costs in installing concrete pad footings, above ground piers, bearers and joists, and fibre cement sheeting. This explains the greater cost for timber substructure over brick in every project. The other result that stands out is the significant external wall cost for a brick veneer system that is significantly greater than the timber clad/timber structural wall envelope. Wall finishes are more expensive for timber due to the external painting of cladding and architraves. In summary, the main cost elements that had the greatest influence on total cost are the substructure, walls and roof in both designs.

\subsection{Construction time}

Time considerations are critical to construction projects. This is due to costs to both builders and clients associated with time delays beyond planned or expected project finish dates. Builders need to allow for ongoing costs associated with establishing and operating the site with items such as the supply of temporary fencing and worker facilities in addition to power and water costs. Delay in building works slows progress payments that can affect cashflow, profits and overheads. The clients are also affected by construction speed, as their return on investment will reduce over time if the project is not completed on the schedule. Losses occur through lost opportunities on money invested and/or ongoing interest on borrowed finances.

The two designs have also been analysed for construction time in calendar days. The approach used is to calculate times for trade activities and their overlap. The comparison of construction time for the two designs is based on current trade practices to examine which design is more efficient. Some activities such as kitchen and bathroom installation would be the same for both designs so these are excluded. However if the floor preparation activities are different, (e.g. floor preparation for the bathroom) the time impact of these activities will be included. The analysis addressed the wall and floor structures in particular, as this is where the most significant differences are between the brick and timber structures.

A schedule estimate has been prepared for both designs using an optimum scheduling method. This involves using industry professionals and industry association guidelines/trade averages applied to both designs. This scheduling allows for the most efficient overlap between trades and the optimum outcome. This research acknowledges that real life projects experience a delay in trade coordination due to supply or lack of supply of trades and other factors such as material availability. However, due to the ambiguity and lack of data for these time delays, they have been omitted from this study. MS Project is the program used to calculate construction time and this program is a commonly used scheduling tool for the Australian construction industry. 
The scheduling of activities accounts for dependencies that occur between trades according to current practice and innovative practices new to the building industry are not used in the calculations (e.g. prefabricated bathroom modules, completed wall or floor panels). The information used for the scheduling has been obtained from industry associations, experienced building professionals, builders, carpenters and other trades people with over 20 years' experience in residential building. Table 11 provides the sources of information for the main structural elements of the building envelope investigated and the size of teams used for calculating the time of completing each element.

Table 11 - Scheduling information sources and trade team numbers

\begin{tabular}{|c|c|c|c|}
\hline Building element & Trade & Number of workers & Information sources \\
\hline Concrete slab footing & Concreters & 4 & Work Safe Victoria \\
\hline \multirow[t]{2}{*}{ Pier holes } & Excavator & 1 & Industry professionals \\
\hline & Labourer/builder & 1 & Industry professionals \\
\hline Piers & Carpenter/labourer & 4 & Builder/carpenter \\
\hline \multirow[t]{2}{*}{ Timber substructure } & Carpenter & 3 & Builder/carpenter \\
\hline & Labourer/apprentice & 1 & Builder/carpenter \\
\hline \multirow[t]{2}{*}{ Wall frames } & Carpenter & 3 & $\begin{array}{l}\text { Builder/carpenter/ } \\
\text { Westruss Co. }\end{array}$ \\
\hline & Labourer/apprentice & 1 & Builder/carpenter \\
\hline \multirow[t]{2}{*}{ Roof framing } & Carpenter & 3 & Builder/carpenter \\
\hline & Labourer/apprentice & 1 & Builder/carpenter \\
\hline \multirow[t]{2}{*}{ Brick work } & Bricklayers & 3 & $\begin{array}{l}\text { National Federation of } \\
\text { Bricklayers and Masonry } \\
\text { Employees }\end{array}$ \\
\hline & Labourer/apprentice & 1 & Builder/bricklayer \\
\hline \multirow[t]{2}{*}{ Wall cladding } & Carpenter & 3 & Builder/carpenter \\
\hline & Labourer/apprentice & 1 & Builder/carpenter \\
\hline \multirow[t]{2}{*}{ Roof tiling } & Roof tilers & 3 & Builder/roof tiler \\
\hline & Labourer/apprentice & 1 & Builder/roof tiler \\
\hline
\end{tabular}

Table 11 displays the information sources used to establish times for the scheduling used in the time modelling comparison between brick and timber. The scheduled work is measured in 8 hour working days however the final results recorded the calendar days from day 1 until the completion of the internal painting. An external validity check has been conducted by an experience builder with over 20 years' experience in residential construction to produce an independent schedule for each construction process without having access to the results of this research. The builder has been provided with the drawings along with the information in Table 11 regarding the size of trade teams. This provided a benchmark tool to check the resulting schedules produced for the study. There are no significant differences between the builders estimate with those found in the study. Results are summarised in Table 12. 
Table 12 - Construction time comparison between brick and timber design

\begin{tabular}{|c|c|c|c|c|}
\hline Project ID & \multirow{2}{*}{$\begin{array}{c}\text { GFA } \\
\mathbf{( m}^{\mathbf{2}} \mathbf{n}\end{array}$} & \multicolumn{2}{|c|}{ Construction time (Calendar days) } & \multirow{2}{*}{$\begin{array}{c}\text { Difference } \\
\text { (Days) }\end{array}$} \\
\cline { 3 - 4 } & 290 & Brick & Timber & 13 \\
\hline 1 & 334 & 74 & 69 & 17 \\
\hline 2 & 171 & 69 & 57 & 11 \\
\hline 3 & 281 & 88 & 58 & 21 \\
\hline 4 & 192 & 59 & 67 & 8 \\
\hline 5 & 246 & 84 & 51 & 15 \\
\hline 6 & 260 & 78 & 69 & 8 \\
\hline 7 & 171 & 71 & 70 & 17 \\
\hline 8 & 240 & 73 & 54 & 8 \\
\hline 9 & 124 & 58 & 65 & 8 \\
\hline 10 & $\mathbf{2 3 1}$ & $\mathbf{7 3 . 6}$ & 50 & $\mathbf{1 2 . 6}$ \\
\hline Mean & & & $\mathbf{6 1}$ & \\
\hline
\end{tabular}

The initial results showed that the brick design has an average of 73.6 days compared to 61 days for the timber design that is a mean of 13 calendar days longer for the brick design. The difference between the timber and brick ranged from 8 days up to 21 days. There is a big difference between the construction time for Projects 2, 4 and 8 that may be explained by the design of the floor slabs and wall envelope plan. These three projects have large concrete ground slabs with large drop edge beams and reinforcing requirements. They also have large volumes of brickwork that included columns and other time consuming bricklaying activities.

The main areas of difference between the brick and timber designs occurred in the setup, coordination between trades, and completion of the concrete slab and brickwork. The brick design with large concrete floor slabs and drop edge or deep internal beams resulted in more time taken to complete the floor structure. The time increase is related more extensive detailed excavation, formwork and reinforcing placement. Concrete floor slabs also have the delay of the waste plumbing installation before the slab can be poured whereas the plumbing in the timber design does not conflict with footing installation. Bricklaying time and the dependencies around its completion are not as integrated as with timber envelope. Timber cladding times ranged from 3-5 days compared to brick that has a minimum completion time of 8 days with a maximum of 17 days for the largest project.

Figure 4 shows an increase in time as the footprint of brick design rises to a point $\left(175 \mathrm{~m}^{2}\right)$ and then decreases. The decreasing times for the larger footprint could be associated with the reduction in brickwork for the single storey projects. The timber design showed less variation in the number of days for the varying footprint. Single storey projects with larger footprints than two storey projects are quicker to erect despite the floor structure size increasing. This may be due to most work being on ground level. Both brick and timber two storey projects require scaffolding for the wall envelope that reduces the efficiencies of both bricklaying and cladding installation. Further research with larger numbers of projects would be beneficial to see more definitive trends associated with footprint and 
envelope area of concrete and brick projects. The only conclusive analysis for time established in this section is that timber construction is quicker than heavy materials and this confirms the results from the literature review.

Figure 4 - Construction schedule compared to building footprint area

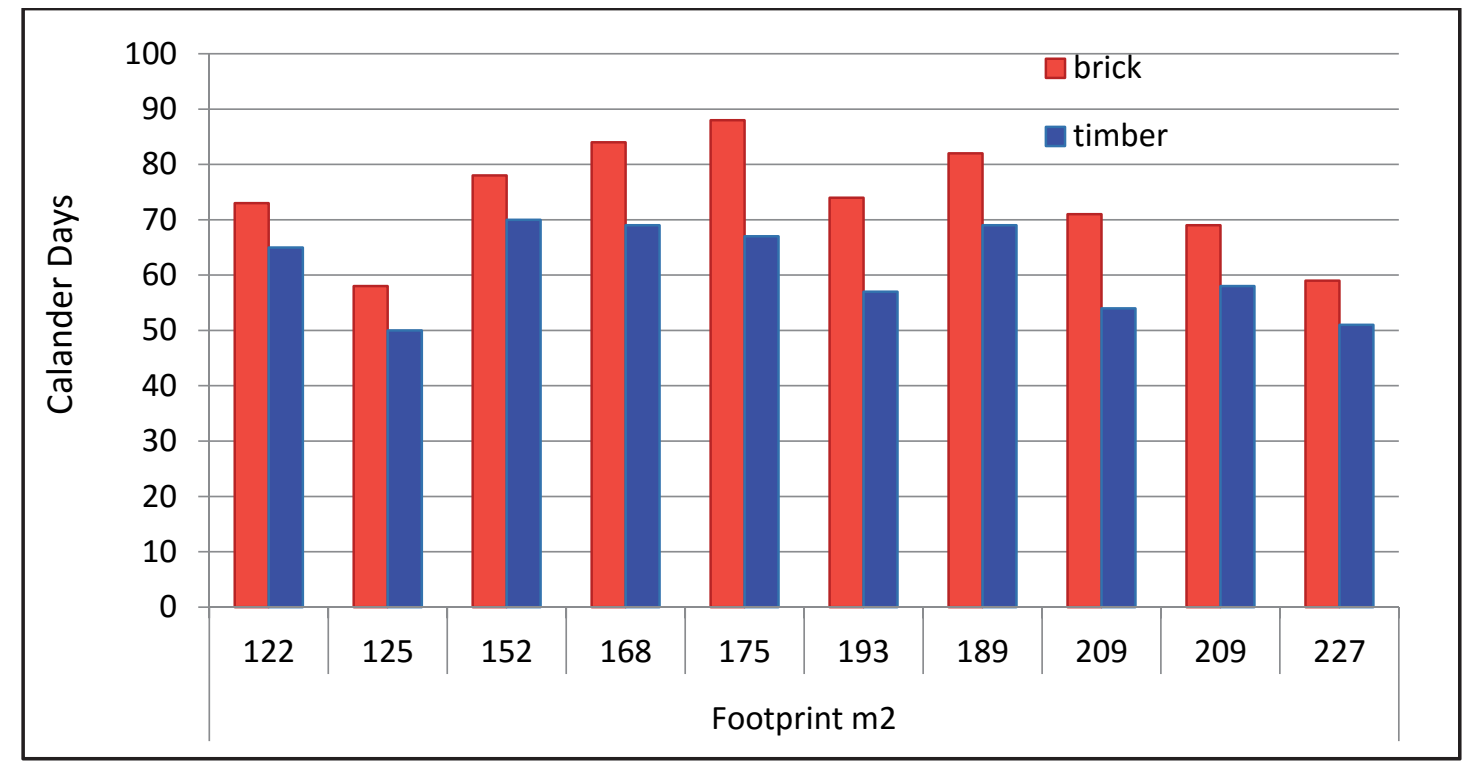

\section{Conclusion}

The research comparing conventional heavy materials with timber has been undertaken using ten case studies by redesigning heavy material projects with a timber envelope equivalent thermal performance. The analysis revealed that a timber envelope can provide benefits over conventional design of brick and concrete in LCE and construction time although the LCC comparison is less significant on a 50 -year period.

The results show that LCC of timber design are on average $2 \%$ per $\mathrm{m}^{2}$ of GFA less than brick design over the 50-year period. The breakdown of LCC reveals that the material and construction cost of timber being $6 \%$ per $\mathrm{m}^{2}$ less than brick although the maintenance cost of timber is $26 \%$ per $\mathrm{m}^{2}$ greater than brick over the 50-year period. However the LCC study does not account for industry efficiencies and increased durability of timber products and external wall finishes that may reduce maintenance costs once they are introduced into the market. End-of-life costs for brick was $30 \%$ per $\mathrm{m}^{2}$ more than timber due to the additional heavy plant required and disposal costs related to the concrete slab and brick envelope.

With regards to LCE the research result shows that timber is a more sustainable material compared to concrete/brick in the conventional design. This has been demonstrated through the lower initial and recurrent embodied energy and end-of-life energy for the timber design. The average LCE is mainly 
consumed in the material and construction, and maintenance phases, with $54 \%$ and $45 \%$ respectively, and with just $1 \%$ energy used at the end-of-life for demolition and disposal. At the material and construction phase, brick design is found to have $18 \%$ more embodied energy than timber. Timber projects on average are more energy intensive to maintain by just $2 \%$ but a lot less than brick design by the construction (18\%) and end-of-life (56\%).

Time components of a residential project are separated into phases of design development, construction, operating and demolition. The focus of the case studies is the construction schedule and result shows that timber redesigned projects is quicker than brick by a range of 8-21 days. Time is viewed as critical to cost savings due to the increasing cost of labour, site establishment and running costs, and the supervision of safety. Timber prefabrication has the potential to further reduce construction time. Construction cost reductions have been identified for timber in the criteria of materials, labour, plant, equipment, material delivery and waste in the literature. Materials are installed with greater speed and lighter equipment, and less plant is required and less labour needed for completion of the structure. In addition, the weight of material delivered is reduced and construction waste is lower than concrete or bricks due to weight. In addition, demolition and disposal of timber structures should be cheaper than the heavy materials because the landfill is measured by weight. Recycling of timber requires less energy than concrete and bricks.

The literature review reveals misperceptions of timber performance of residential development. However the research results demonstrate that thermal performance of brick and timber designs can be achieved through changes to the building envelope. It also shows that, based on the thermal equivalent redesigned timber project, the performance in terms of LCE, LCC and construction time is more efficient than the original brick design.

The restraints of this research include the limited number of case studies used, the types of blocks used and the case studies being based in one state in New South Wales. Future research could benefit from a nationwide study of comparative cases to account for different building practices, access to resources and costs of labour and materials. Real life case studies using the same design on the same block would provide sound data on the comparison between heavy materials and timber. However this type of study would be both expensive in the project and data collection costs, particularly if a number of projects were undertaken. Finally, further study could be undertaken on sites with a variety of slopes and foundation materials. 


\section{References}

ABS 2014, Monthly building approvals, Australian Bureau of Statistics, Australian government.

Alexander, J., Hague, J, Bongers, F., Imamura, Y. \& Roberts, M. 2014, The resistance of Accoya and Tricoya to attack by wood-destroying fungi and termites, Sweden.

Australian Government 2012, Kyoto Protocol, Department of the Environment, Commonwealth of Australia, Canberra.

Bayne, K. \& Taylor, S. 2006, Attitudes to the use of Wood as a Structural Material in Nonresidential Building Applications: Opportunities for Growth, Melbourne.

Bysheim, K. \& Nyrud, A. 2009, Using a predictive model to analyse architect's intentions of using wood in urban construction, Forest products journal, vol. 59, no. 7/8, pp. 65-74.

Carre, A. 2011, A comparative life cycle assessment of alternate constructions of a typical Australian house design, RMIT University, Melbourne.

Cox, P., Freeland, J. \& Stacey, W. 1980, Rude timber buildings in Australia, 2nd Edition, Angus and Robinsons, Australia.

Ding, G. \& Forsythe, P. 2016, A comparative study of floor construction on sloping sites: an analysis of cumulative energy demand and greenhouse gas emissions, Construction Economics and Building, vol. 16, no. 1, pp. 33-49.

Flower D.J.M. \& Sanjayan J.G. 2007, Greenhouse Gas Emissions due to Concrete Manufacture, International Journal of Life Cycle Assessment, vol. 12, no 5, pp 282-288.

Gold, S. \& Rubik, F. 2009, Consumer attitudes towards timber as a construction material and towards timber frame houses - selected findings of a representative survey among the German population, Journal of Cleaner Production, vol. 17, no. 2, pp. 303-9.

Gustavsson, L. \& Joelsson, A. 2010, Life cycle primary energy analysis of residential buildings, Energy and Buildings, vol. 42, no. 2, pp. 210-20.

Holmes, M., Crews, K. \& Ding, G. 2011, The influence building codes and fire regulations have on multistorey timber construction in Australia, paper presented to the World Sustainable Building Conference Helsinki, Finland

IBISworld 2011, House Construction in Australia

Independent Pricing and Regulatory Tribunal (IPART) of NSW 2013, Review of regulated retail prices and charges for electricity: From 1 July 2013 to 30 June 2016, IPART, Sydney.

John, S., Nebel, B., Perez, N. \& Buchanan, A. 2009, Environmental Impacts of Multi-Storey Buildings Using Different Construction Materials New Zealand Ministry of Agriculture and Forestry 200802 .

John, S., Mulligan, K., Perez, N., Love, S. \& Page, I. 2011, Cost, time and environmental impacts of the construction of the new NMIT Arts and Media building, Department of Civil and Natural Resources Engineering Christchurch, New Zealand

Kelly, A. 2011, House construction in Australia, IBISWorld, Sydney.

Knowles, C., Theodoropoulos, C., Griffin, C. \& Allen, J. 2010, Designers' view of green structural materials: Implications for wood science research, paper presented to the International Convention of Society of Wood Sscience and Technology and United Nations Economic Commission for Europe, Geneva.

Kolb, J. 2008, Systems in Timber Engineering, 1st Edition, Birkhauser, Uttwill.

Lennon, T., Hopkin, D., El-Rimawi, J. \& Silberschmidt, V. 2010, Large scale natural fire tests on protected engineered timber floor systems, Fire Safety Journal, vol. 45, no. 3, pp. 168-82. 
Ljunggren, F., Simmons, C. \& Hagberg, K. 2014, Correlation between sound insulation and occupants' perception - Proposal of alternative single number rating of impact sound, Applied Acoustics, vol. 85, pp. 57-68.

Low, K. \& Mahendrarajah, S. 2010, Future directions for the Australian forest industry, ABARE, Canberra.

Mahapatra, K. \& Gustavsson, L. 2009, General conditions for construction of multi-storey wooden buildings in Western Europe, Vaxjo University, Ostersund.

Monahan, J. \& Powell, J.C. 2011, An embodied carbon and energy analysis of modern methods of construction in housing: A case study using a lifecycle assessment framework, Energy and Buildings, vol. 43, no. 1, pp. 179-88.

Moss, P.J., Dhakal, R.P., Wang, G. \& Buchanan, A.H. 2008, The fire behaviour of multi-bay, two-way reinforced concrete slabs, Engineering Structures, vol. 30, no. 12, pp. 3566-73.

Mwashi, A., Williams, R. \& Iwaro, J. 2011, Modeling the performance of residential building envelopes, Energy and buildings, no. 43, pp. 2108-17.

Norgate, T.E, Jahanshahi, S, Rankin, W.J, 2007, Assessing the environmental impact of metal production processes. Journal of cleaner production, vol. 15, no.8-9.

Nolan, G. 2009, Timber in multi-residential, commercial and industrial building: Recognising opportunities and constraints, Centre for Sustainable Architecture with Wood, Tasmania.

NSW Department of Planning 2011, Multi-dwelling outcomes 2006-09 Basix ongoing monitoring program, Department of planning, Sydney.

Perez, N. 2008, The infuence of construction materials on life-cycle energy use and carbon dioxide emissions of medium size commercial buildinga, Masters thesis, Victoria University of Wellington, Wellington.

Ratnala, R. \& Shrestha, R. 2010, Interim report-acoustic performance of timber flooring systems, University of Technology Sydney, Sydney.

RICS 2006, Life expectancy of building components, BCIS, London, UK

Roos, A., Woxblom, L. \& McCluskey, D. 2010, The influence of Architects and Structural Engineers on Timber in Construction-Perception and Roles', Silva Fennica, vol. 44, no. 5, pp. 871-84.

University of Tasmania 2008, Five star thermal performance project.

URS Corporation Australia 2010, Timber Market Survey.

URS Forestry 2007, Timber market survey 2006, Report for Forests NSW, Sydney.

Wagner, E. \& Hanson, E. 2004, 'Environmental attributes of wood products: Context and relevance for U.S architects', Forest products journal, no. 54, pp. 19-25.

Yeomans, D. 2008, 'Specifying buildings: A design management perspective', Elsevier. 